\title{
Letter From the Editor
}

\section{J. Mitchell Miller ${ }^{1}$}

Published online: 4 July 2019

(C) Southern Criminal Justice Association 2019

Welcome to Volume 44, Issue 4 of the American Journal of Criminal Justice! Guest Editor, renown criminologist Marvin Krohn, has assembled and impressive combination of empirical works and essays examining applied criminology and public policy. These articles, many derived from Dr. Krohn's invited Presidential Panel presentations at the 2018 Southern Criminal Justice Association Annual Conference in Pensacola Beach, address a wide range of justice and policy areas. The issue begins and ends with an overview of the role and import of applied criminology, generally, and consideration of how research-practitioner partnerships might better address our crime challenges by Krohn and well-known scholar Thomas Blomberg, respectively. Leading scholars address various topics in between, ranging from race effects in juvenile courts, national gang policy, and cyber-bullying to environmental crime, gun policy, and capital punishment. Hopefully, there is something of interest and value for everyone.

Meanwhile, the American Journal of Criminal Justice will be exhibiting at upcoming 2019 regional, national, and international conferences. Please stop by and say hello!

Publisher's Note Springer Nature remains neutral with regard to jurisdictional claims in published maps and institutional affiliations.

J. Mitchell Miller

mitch.miller@unf.edu

1 University of North Florida, Jacksonville, FL, USA 